\title{
STRUCTURAL DESIGN AND SIZING OF A METALLIC CRYOTANK CONCEPT
}

\author{
David W. Sleight ${ }^{*}$, Robert A. Martin ${ }^{\dagger}$, and Theodore F. Johnson ${ }^{\ddagger}$ \\ NASA Langley Research Center, Hampton, VA, 23681
}

\begin{abstract}
This paper presents the structural design and sizing details of a 33-foot $(10 \mathrm{~m})$ metallic cryotank concept used as the reference design to compare with the composite cryotank concepts developed by industry as part of NASA's Composite Cryotank Technology Development (CCTD) Project. The structural design methodology and analysis results for the metallic cryotank concept are reported in the paper. The paper describes the details of the metallic cryotank sizing assumptions for the baseline and reference tank designs. In particular, the paper discusses the details of the cryotank weld land design and analyses performed to obtain a reduced weight metallic cryotank design using current materials and manufacturing techniques. The paper also discusses advanced manufacturing techniques to spin-form the cryotank domes and compares the potential mass savings to current friction stir-welded technology.
\end{abstract}

\section{Introduction}

$\mathrm{N}$ ASA is currently developing technologies needed to build a second-generation reusable launch vehicle to replace the Space Shuttle. Part of this effort includes the development of reusable composite and metallic liquid hydrogen (LH2) cryogenic tanks (also known as cryotanks) that reduce the overall cost and weight while maintaining the reliability of existing designs. NASA's Game Changing Development Program (GCDP) in the newly formed Space Technology Mission Directorate has the objective to mature advanced space technologies that may lead to entirely new approaches for future space missions and spin-off capabilities for NASA, DOD, and industry.

The Composite Cryotank Technologies Demonstration (CCTD) Project which is a part of the GCDP is developing new technologies using advanced composite materials that could be applied to multiple future NASA missions, including human space exploration beyond low Earth orbit. During fiscal year 2011, NASA and four industry partners participated in Phase I of the CCTD Project to develop conceptual designs for a 33-foot (10 m) diameter composite cryotank with a goal of achieving a 25\% cost savings and $30 \%$ weight savings when compared to current state-of-the-art aluminum-lithium tanks. Three of the four industry teams (Boeing, Lockheed Martin, and Northrop Grumman) were tasked with developing composite cryotank designs. ${ }^{1-3}$ The NASA team developed an aluminum lithium alloy cryotank design that incorporated Technology Readiness Level ${ }^{4}$ (TRL) 9 structural design methodology, materials, and manufacturing techniques to serve as a reference design for comparison to the composite cryotank designs. The reference design was based heavily on the Space Shuttle Super LightWeight Tank $^{5}$ (SLWT) and the Ares I liquid hydrogen (LH2) tank. The industry teams used this TRL 9 reference design to develop manufacturing cost models and to serve as a basis for weight comparison to the composite cryotank concepts. The composite cryotank concepts were based on low to mid TRL structural concepts and manufacturing techniques. Although it was the stated objective of the CCTD program, some felt that it was unfair to compare the weight of the low to mid TRL composite designs to a mature TRL 9+ metallic design. Because of this, the NASA team performed additional trade studies to evaluate the potential weight saving benefits of incorporating lower TRL advanced metallic manufacturing techniques in the metallic reference design.

\footnotetext{
* Aerospace Engineer, Durability, Damage Tolerance, and Reliability Branch, MS 188E, AIAA Senior Member.

${ }^{\dagger}$ Aerospace Engineer, Mechanical Systems Branch, MS 432.

${ }^{\ddagger}$ Assistant Branch Head, Structural and Thermal Systems Branch, MS 431, AIAA Senior Member.
}

1

American Institute of Aeronautics and Astronautics 
The purpose of this paper is to describe and discuss the detailed design and sizing analyses that led to the TRL 9 metallic cryotank reference design. The paper includes the design and sizing methodology, materials choices and restrictions, and manufacturing techniques. The paper also explores the potential weight benefits of employing advanced manufacturing techniques to spin-form the cryotank domes. ${ }^{6-8}$

\section{Requirements and Loads}

The reference geometry for the 33-foot diameter cryotank concept is shown in Figure 1. The loads, length, and volume were based on a 33-foot diameter Ares V Earth Departure Stage (EDS) liquid hydrogen tank. The total length of the tank from dome top to dome bottom was nearly 34 feet long and the barrel section of the tank was 10.6 feet long. The domes of the reference cryotank design were ellipsoidal, with a 0.7071 dome height to dome radius ratio. Tables 1 and 2 include the geometric and structural requirements developed by NASA and the industry teams for the cryotank design and testing. Table 1 lists the general requirements including Government furnished information (GFI) applicable to both the metallic and composite cryotank concepts. Table 2 lists separate factor of safety and material property requirements only applicable to the metallic cryotank concept. The required factors of safety were obtained from the NASA STD-5001A ${ }^{9}$ and CxP $70135^{10}$ documents. A maximum design pressure (MDP) of 46.2 psi was used to size the cryotank concepts. This includes the combination of the maximum expected operating pressure (MEOP) or ullage pressure of $42.0 \mathrm{psi}$ and a hydrostatic head pressure of $4.2 \mathrm{psi}$. A maximum stabilization pressure of 20 psi was selected as the residual pressure in the cryotank for the mechanical load cases. A zero pressure was set for a failure load condition during an unsuccessful launch. A common global buckling knockdown factor was used for all concepts regardless of the wall configuration or material. ${ }^{11}$

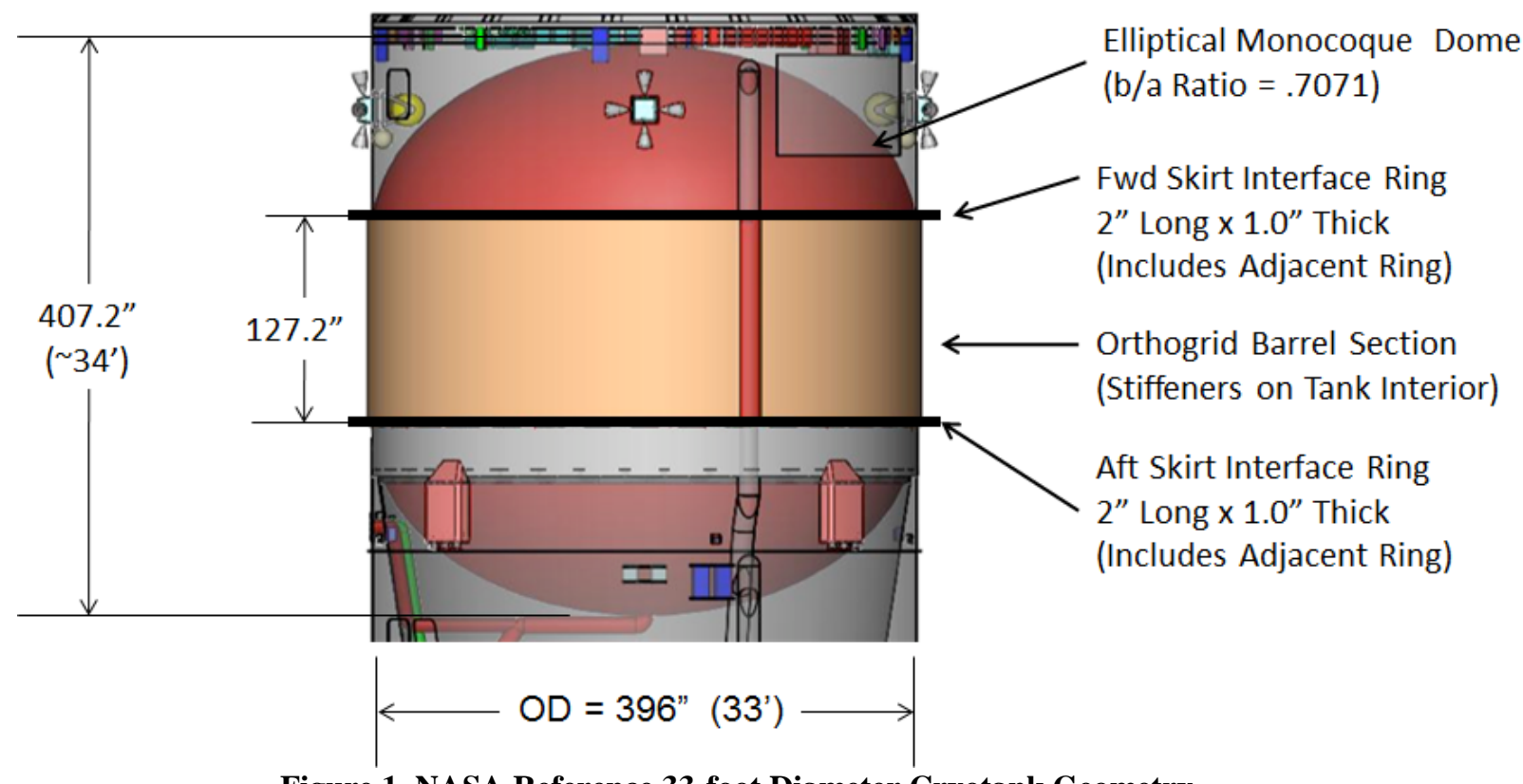

Figure 1. NASA Reference 33-foot Diameter Cryotank Geometry. 
Table 1. Compiled CCTD Requirements for a 33-foot Diameter Cryotank.

\begin{tabular}{|c|c|c|c|}
\hline Criterion & $\begin{array}{c}\text { Ten Meter Tank } \\
\text { Requirement }\end{array}$ & Reference & Baseline Study Value \\
\hline \multirow{4}{*}{ Geometry } & $\begin{array}{l}\text { Tank cylinder wall median } \\
\text { diameter }\end{array}$ & NASA GFI & 396 in (33 ft) \\
\hline & Tank volume & NASA GFI & $38,700,000$ cu. in. \\
\hline & Dome height-to-radius ratio & Assumed & 0.707 (approx.) \\
\hline & Relative length of skirts & Assumed & Forward and aft skirts are equal in length \\
\hline \multirow{2}{*}{$\begin{array}{l}\text { Environments - } \\
\text { Mechanical Loads }\end{array}$} & React internal pressure loads & NASA GFI & $\begin{array}{l}\text { MEOP = } 46.2 \text { psi, Head pressure of } 4.2 \text { psi } \\
\text { included }\end{array}$ \\
\hline & React flight loads & NASA GFI & $\begin{array}{l}\text { Effective compressive line load }=-2,495.9 \text { lb./in, } \\
\text { Axial }\left(\mathrm{F}_{\mathrm{x}}\right)=-705,480 \mathrm{lbs} \text {, Shear load }\left(\mathrm{F}_{\mathrm{y}}\right)= \\
\text { 342,119 lbs., Moment }\left(\mathrm{M}_{\mathrm{z}}\right)=237,560,117 \mathrm{lbs} \text {./in }\end{array}$ \\
\hline \multirow{2}{*}{$\begin{array}{c}\text { Operating } \\
\text { Temperatures } \\
\end{array}$} & Minimum & Assumed & $-423^{\circ} \mathrm{F}$ \\
\hline & Maximum & Assumed & $250^{\circ} \mathrm{F}$ \\
\hline \multirow{4}{*}{$\begin{array}{l}\text { Operational } \\
\text { Requirements }\end{array}$} & $\begin{array}{l}\text { Maximum stabilizing } \\
\text { pressure during flight }\end{array}$ & NASA GFI & 20 psi \\
\hline & Leak rate allowable & NASA GFI & $10^{-3}$ scc/sec/in ${ }^{2}$ \\
\hline & $\begin{array}{l}\text { Minimum stabilizing } \\
\text { pressure during flight }\end{array}$ & Assumed & 0 @ failed condition FS 1.0 \\
\hline & Access opening & Assumed & 30 in Diameter \\
\hline
\end{tabular}

Table 2. CCTD Requirements for a Metallic Cryotank.

\begin{tabular}{|c|c|c|c|}
\hline Criterion & $\begin{array}{c}\text { Ten Meter Tank } \\
\text { Requirement }\end{array}$ & Reference & Baseline Study Value \\
\hline \multirow{4}{*}{$\begin{array}{l}\text { Design Factors of } \\
\text { Safety }\end{array}$} & Proof test factor & NASA 5001A & 1.0 \\
\hline & $\begin{array}{l}\text { Pressurized structure design } \\
\text { factor for limit }\end{array}$ & CxP 70135 & 1.1 \\
\hline & $\begin{array}{l}\text { Pressurized structure design } \\
\text { factor for ultimate }\end{array}$ & CxP 70135 & 1.4 \\
\hline & $\begin{array}{l}\text { Compression stability } \\
\text { knockdown factor }\end{array}$ & Assumed & 0.65 \\
\hline
\end{tabular}

A schematic of the applied loads and boundary conditions for the cryotank concepts is shown in Figure 2. The load cases used in the design of the metallic cryotank concept are listed in Table 3 and included a room temperature proof load case, maximum compression/tension load cases, as well as a tank failure load case. The cryotank designs had an integral skirt that extended beyond the T-Joints at the tank dome/barrel interface. The flight launch loads were applied as component loads $\left(\mathrm{F}_{\mathrm{x}}, \mathrm{F}_{\mathrm{y}}\right.$, and $\left.\mathrm{M}_{\mathrm{z}}\right)$ to the top of the forward skirt extension. A fixed boundary condition was applied to the bottom of the aft skirt extension.

Table 3. Loads Cases for Metallic Cryotank Concept.

\begin{tabular}{|c|c|c|c|c|c|c|}
\hline $\begin{array}{c}\text { Load Case } \\
\text { No. }\end{array}$ & Load Case & $\begin{array}{c}\text { Axial Load } \\
\text { (lbs.) }\end{array}$ & $\begin{array}{c}\text { Shear Load } \\
\text { (lbs.) }\end{array}$ & $\begin{array}{l}\text { Moment } \\
\text { (in-lbs.) }\end{array}$ & $\begin{array}{c}\text { Internal } \\
\text { Pressure } \\
\text { (psi) }\end{array}$ & Metallic FOS \\
\hline 1 & $\begin{array}{c}\text { Room Temperature } \\
\text { Proof } \\
\end{array}$ & - & - & - & $44.1^{*}$ & $\begin{array}{c}\text { 95\% Yield } \\
\text { @ Test Temp } \\
\end{array}$ \\
\hline 2 & Max. Compression & $-F_{x}$ & $\mathrm{~F}_{\mathrm{y}}$ & $\mathrm{M}_{\mathrm{z}}$ & $20^{\ddagger}$ & $\begin{array}{c}1.1 \text { Yield } \\
1.4 \text { Ultimate } \\
\end{array}$ \\
\hline 3 & Max. Tension & $-F_{x}$ & $\mathrm{~F}_{\mathrm{y}}$ & $\mathrm{M}_{\mathrm{z}}$ & 46.2 & $\begin{array}{c}1.1 \text { Yield } \\
1.4 \text { Ultimate }\end{array}$ \\
\hline 4 & $\begin{array}{c}\text { Internal Pressure } \\
\text { Failure }\end{array}$ & $-F_{x}$ & $\mathrm{~F}_{\mathrm{y}}$ & $\mathrm{M}_{\mathrm{z}}$ & 0 & 1.0 Ultimate \\
\hline
\end{tabular}

* The proof load factor of 1.05 (per NASA-STD-5001A) was reduced to 0.955 due to lack of cryogenic material property enhancement at room temperature and to avoid yielding.

‡ Pressure load factor is 1.0 to reduce pressure stabilization 


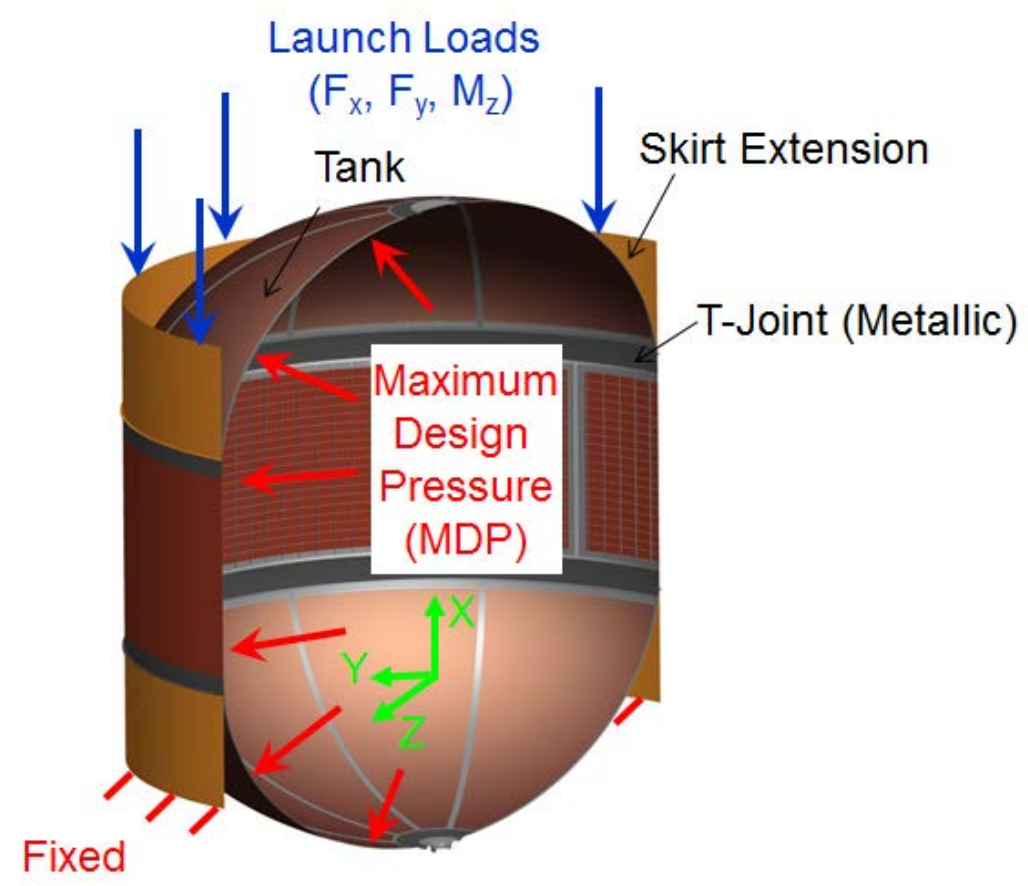

Figure 2. Cryotank Boundary Conditions and Applied Loads.

\section{Metallic Cryotank Concept}

A 33-foot diameter metallic cryotank concept was developed to serve as a cost and weight baseline for the industry-designed, composite cryotanks developed under the Phase I of the CCTD Project. The metallic concept shown in Figure 3 incorporates TRL 9+ materials and manufacturing techniques and incorporates proven structural design features used in the Space Shuttle SLWT and Ares I $\mathrm{LH}_{2}$ cryotank designs. The primary cryotank structure consists of upper and lower monocoque domes, and an orthogrid-stiffened barrel section designed with the Al-Li 2195-T8 Alloy. The remaining components were designed with Al 2219-T87 alloy. Details of the upper dome, lower dome, and barrel components of the metallic cryotank concept are shown in Figures 4, 5, and 6, respectively. Current Al-Li stock size limitations dictate that dome components be manufactured from ten gore segments that are welded together with friction stir welding. Each of the dome and barrel components required a four inch wide weld land (2 inch/edge) to facilitate manufacturing and inspection. A single piece T-Joint is incorporated between the dome gores and barrel components. The T-Joint geometry does not allow the use of Al-Li 2195 alloy so this component is designed to be manufactured from a single piece, 2219-T87 aluminum, roll ring forging. The upper and lower dome caps are 59" in diameter. A 30-inch diameter access hole and a fill/drain sump are included in the lower dome cap design. The orthogrid barrel section also was limited to 10 segments due to stock size limitations. The orthogrid barrel section design included skin buildups near the end weld lands and later incorporated edge weld land stiffeners. Items omitted from this trade study included a $\mathrm{LH}_{2}$ vent, a recirculation line, anti-vortex baffles, and bulkhead fittings for electrical and instrumentation lines. 


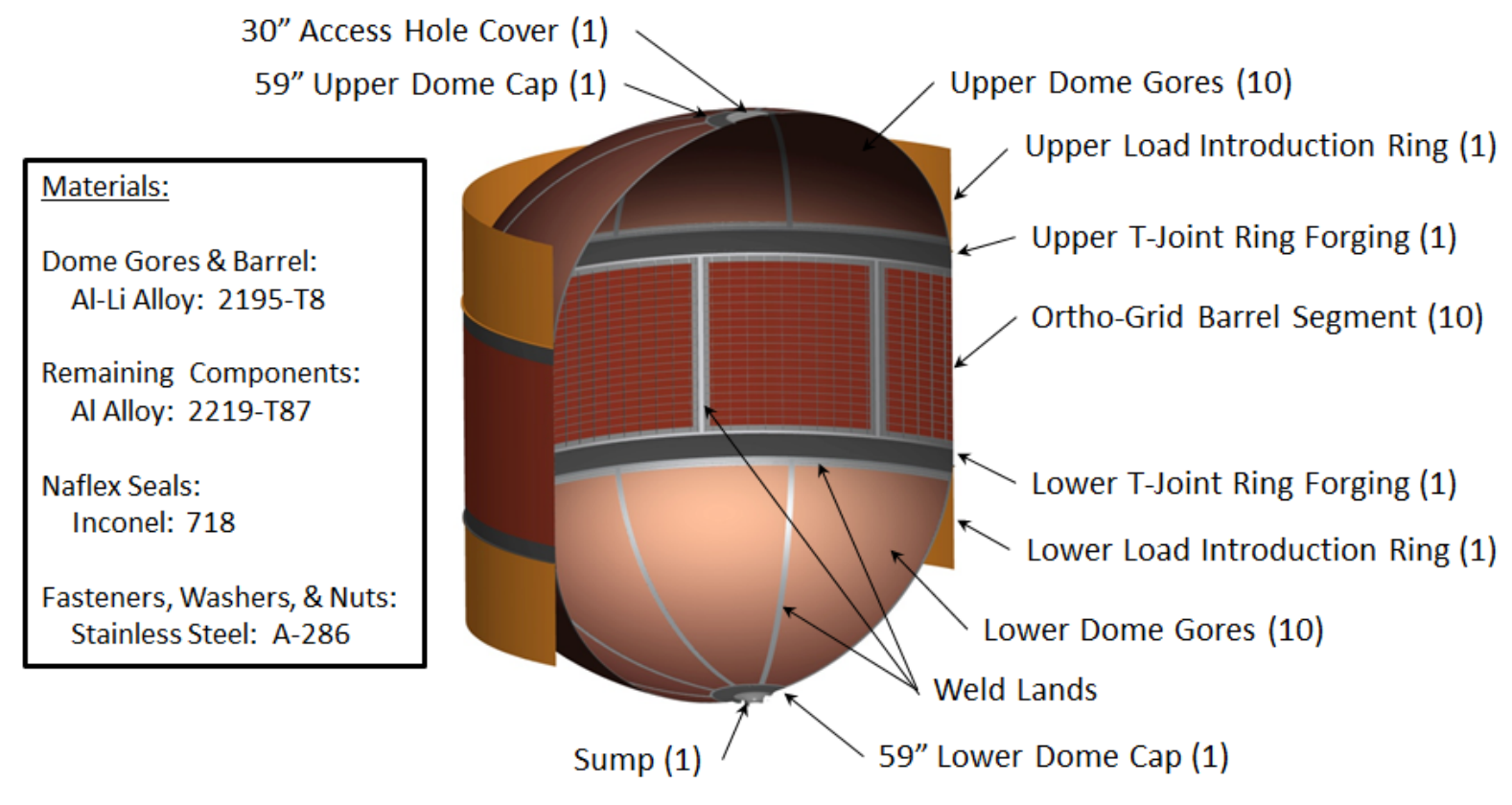

Figure 3. NASA Al-Li Design Metallic Cryotank Concept with 59 in. Dome Caps.

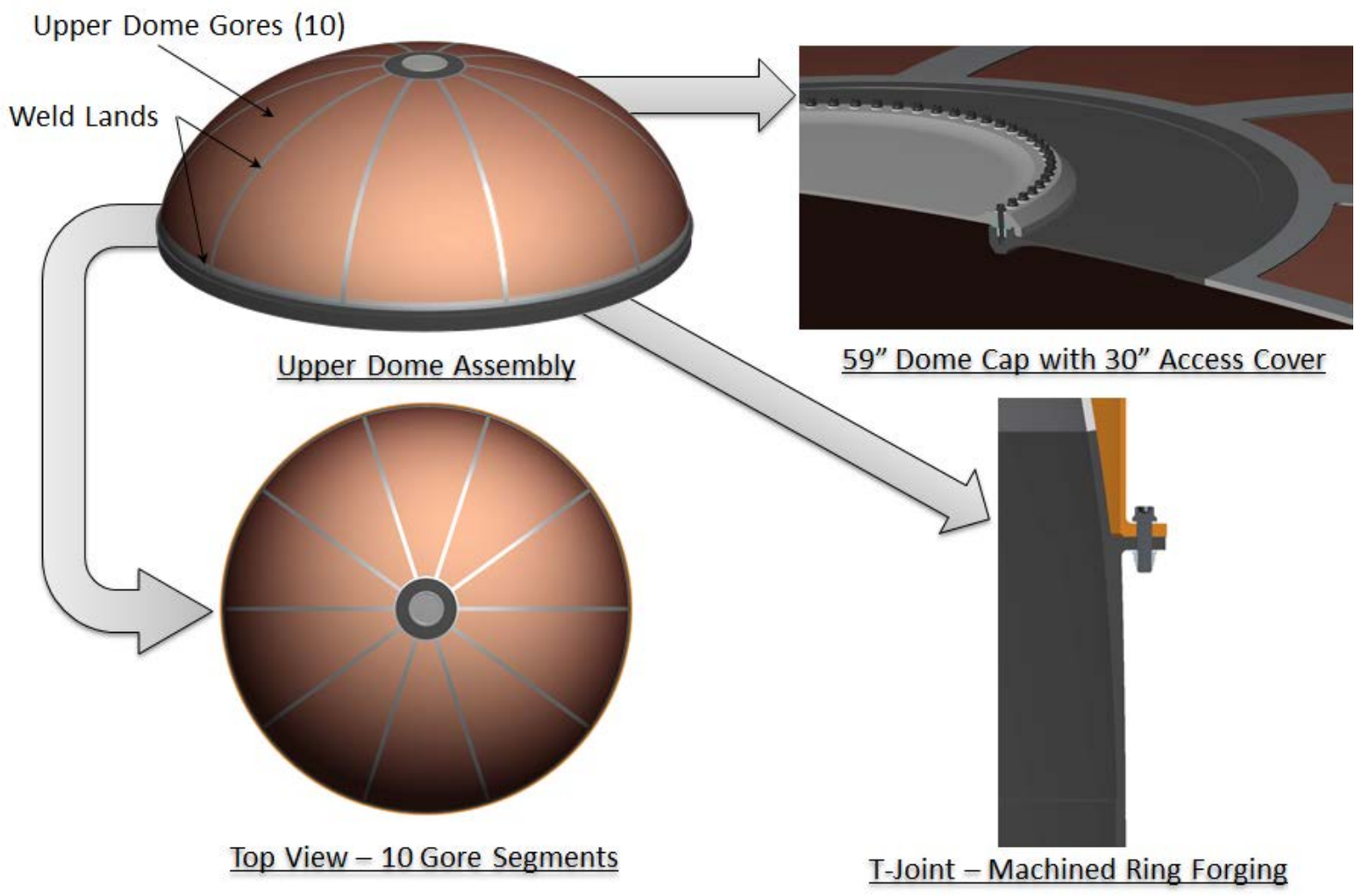

Figure 4. NASA Al-Li Design Upper Dome Components.

5

American Institute of Aeronautics and Astronautics 


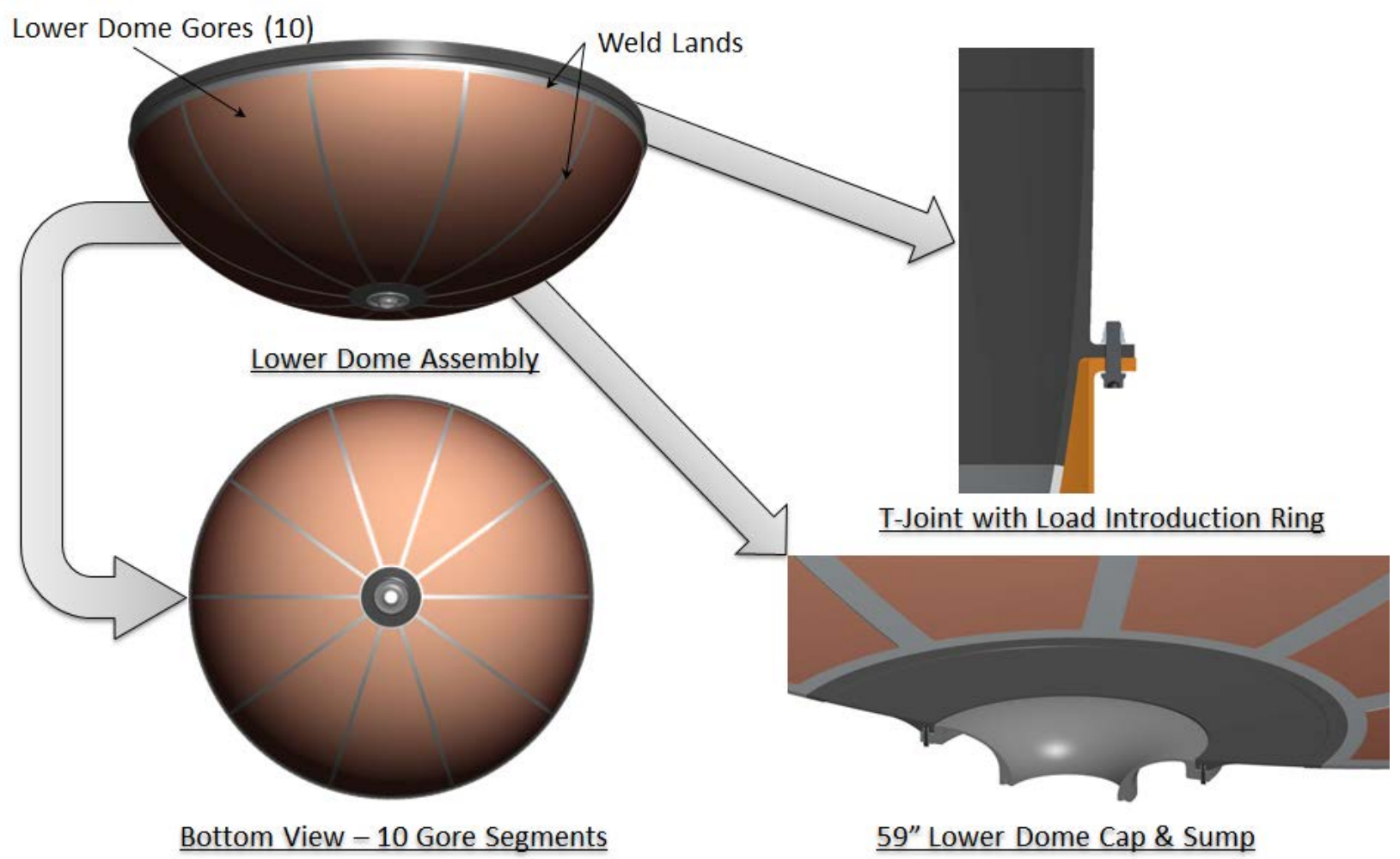

Figure 5. NASA Al-Li Design Lower Dome Components.

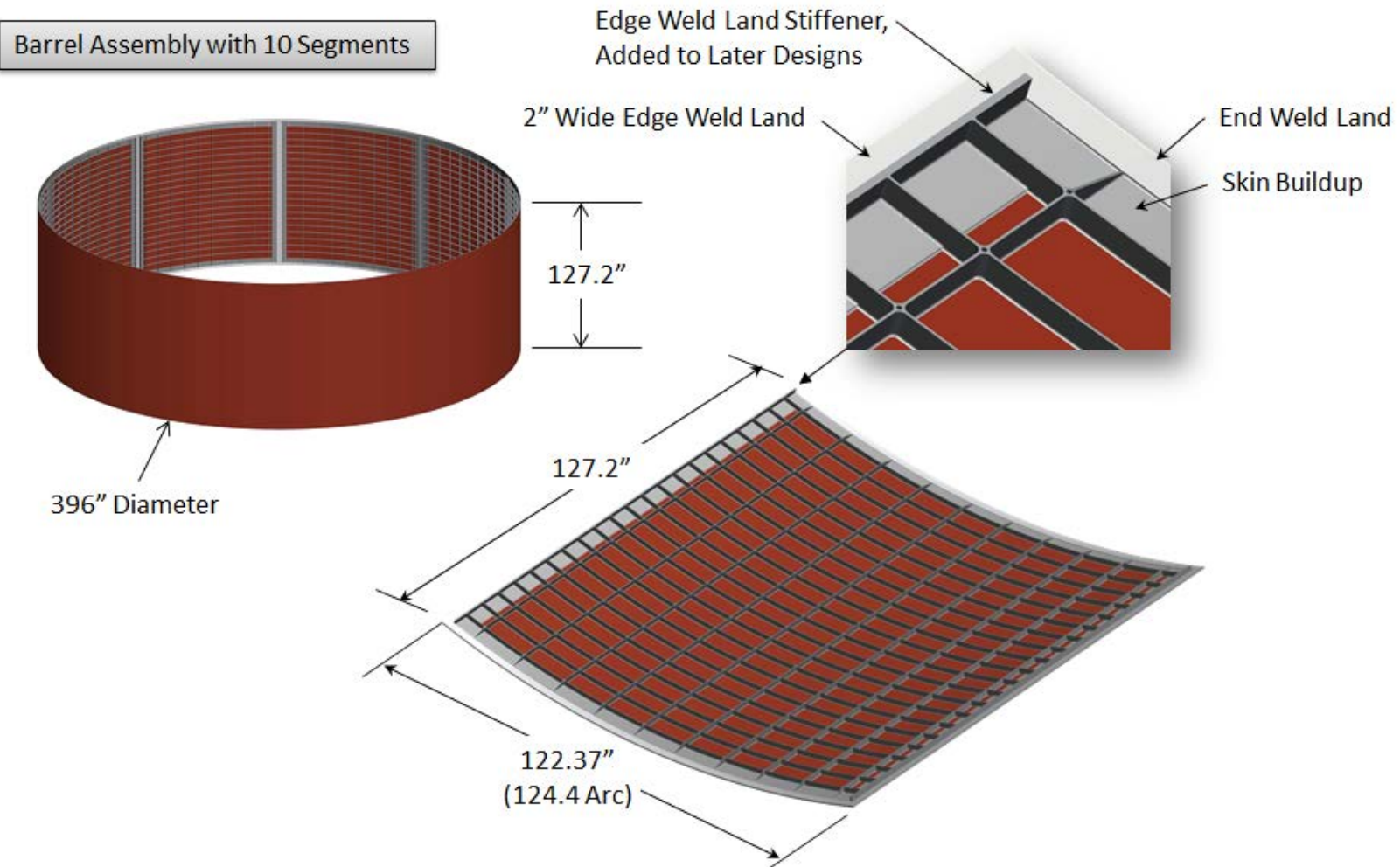

Figure 6. NASA Al-Li Design Orthogrid Barrel Components.

6

American Institute of Aeronautics and Astronautics 


\section{Structural Design and Analysis}

The structural sizing and analysis methodology shown in Figure 7 was used in the metallic cryotank design process. As discussed previously, the design process was started using heritage designs based on previous NASA programs. A finite element analysis (FEA) shell model shown in Figure 8 of the metallic cryotank was developed. The FE model has shell elements to model the structural components of the metallic cryotank design including the monocoque domes, extension skirts, orthogrid panels, weld lands, and the T-Joint rings. HyperSizer ${ }^{\circledR}$ (Ref. 12) and MSC Nastran ${ }^{\mathrm{TM}}$ (Ref. 13) were used to size the cryotank components for strength and local buckling. HyperSizer sizes the sections of the tank including the stiffened orthogrid section and outputs the shell properties as smeared orthotropic material properties. Next, Nastran was used to check for global buckling and the first global buckling eigenvalue was compared to the minimum buckling eigenvalue. If the minimum global bucking eigenvalue was not met, then aspects of the metallic cryotank design such as thicknesses or panel heights had to be manually adjusted until the minimum global buckling eigenvalue was satisfied. Finally, the Computer Aided Design (CAD) models were updated based on the FEA sizing results and the final weights were reported.

For the structural sizing study, the Al-Li 2195-T8 alloy was used for the upper dome, lower dome, and orthogrid barrel sections of the tank. The T-Joints and monocoque tank skirts were sized with 2219-T87 aluminum. The weld lands were sized with reduced Al-Li 2195-T8 alloy strength properties. Stock size restrictions on the Al-Li 2195-T8 alloy limited the maximum orthogrid stiffener height to 1.65 inches, determined the number of weld lands, and forced the use of a different aluminum alloy in the T-Joints. The domes and barrel section of the cryotank had to be designed with ten separate pieces due to the 130-inch x 246-inch Al-Li 2195-T8 stock size limitation. Other minimum requirements on the Al-Li 2195-T8 alloy were a minimum orthogrid skin of 0.084" and a minimum stiffener thickness of 0.055 ”.

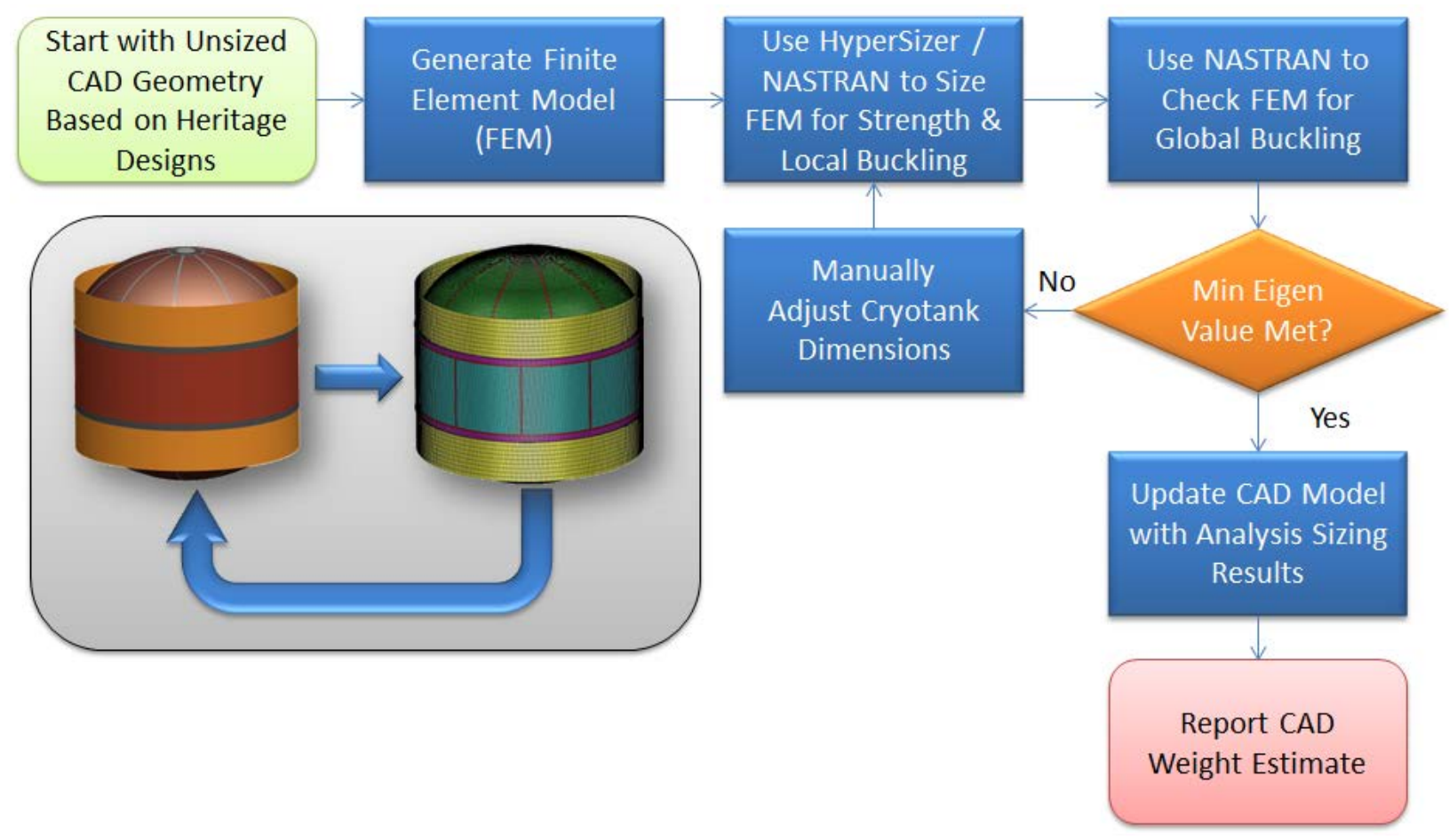

Figure 7. Structural Design and Analysis Methodology for Metallic Cryotank Concept. 


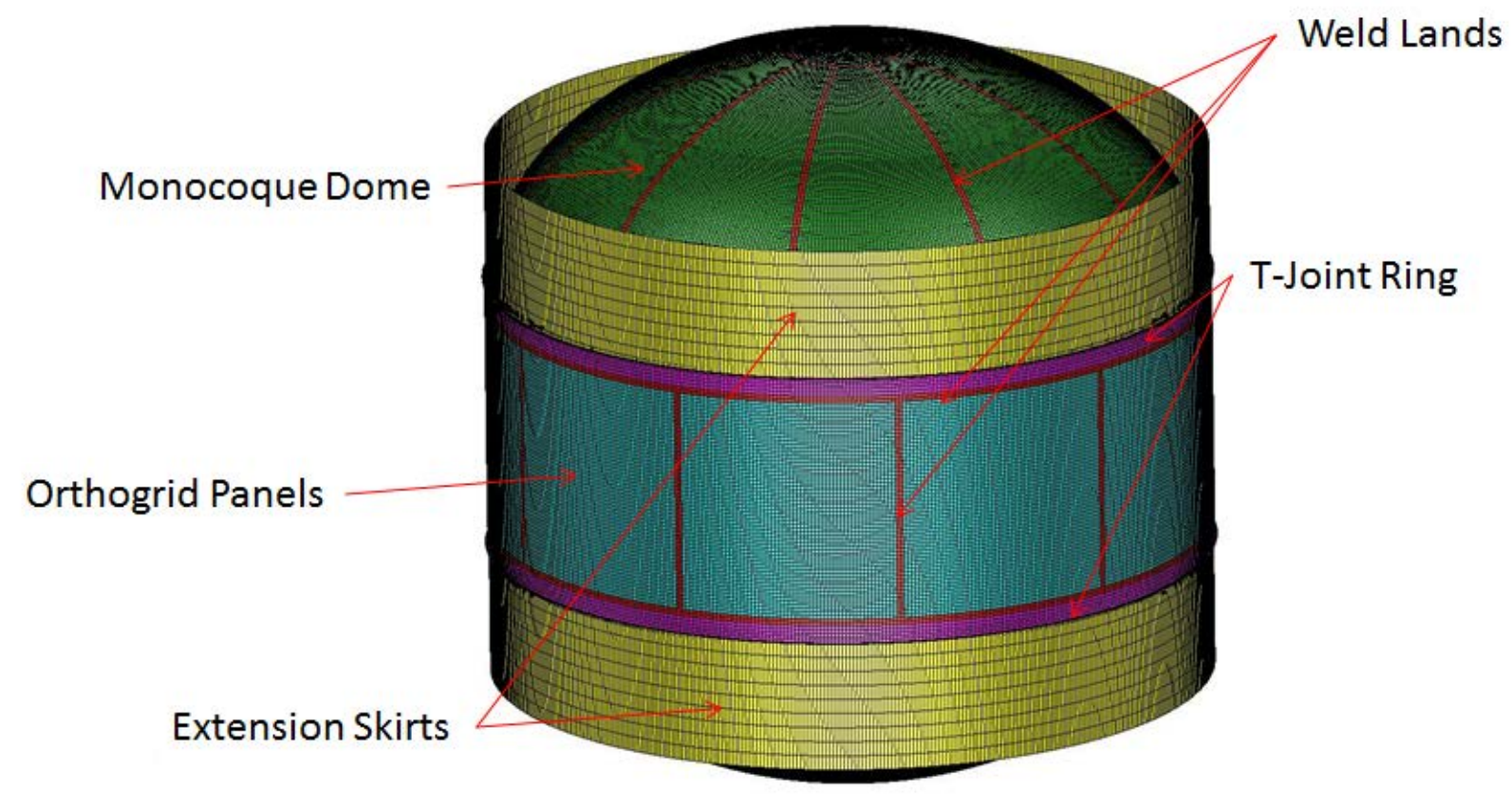

Figure 8. Metallic Cryotank Concept Finite Element Model.

Three sizing studies were performed on the metallic cryotank design. The assumptions and sizing results for each study are described in the sections below.

\section{A. Baseline Design}

In the baseline design, the following design assumptions were assumed in the metallic cryotank sizing:

1) All machining performed on one side of gores and barrel sections

2) Constant weld lands thickness without steps or tapers and sized by thickest weld land region

3) Unitized, skirt extension wall thickness of 0.250 ”

The primary baseline design weight driver was the original weld land design pictured in Figure 9. The cryotank welds have a lower strength than the acreage regions of the tank. As the weld land regions were thickened to compensate for the lower strength of the welds, the local stiffness increased and more axial load was drawn to the weld land regions causing them to buckle. The initial sized metallic cryotank design using the finite element model and HyperSizer with smeared orthogrid material properties yielded weld lands in the barrel section that were 0.680 " thick, almost twice the thickness of heritage designs. The weld land thicknesses in the domes were a constant 0.450 " thickness. The baseline metallic cryotank CAD mass was 12,143 lbs. with the weld lands in the domes and barrel sections accounting for over $20 \%$ of the mass. 


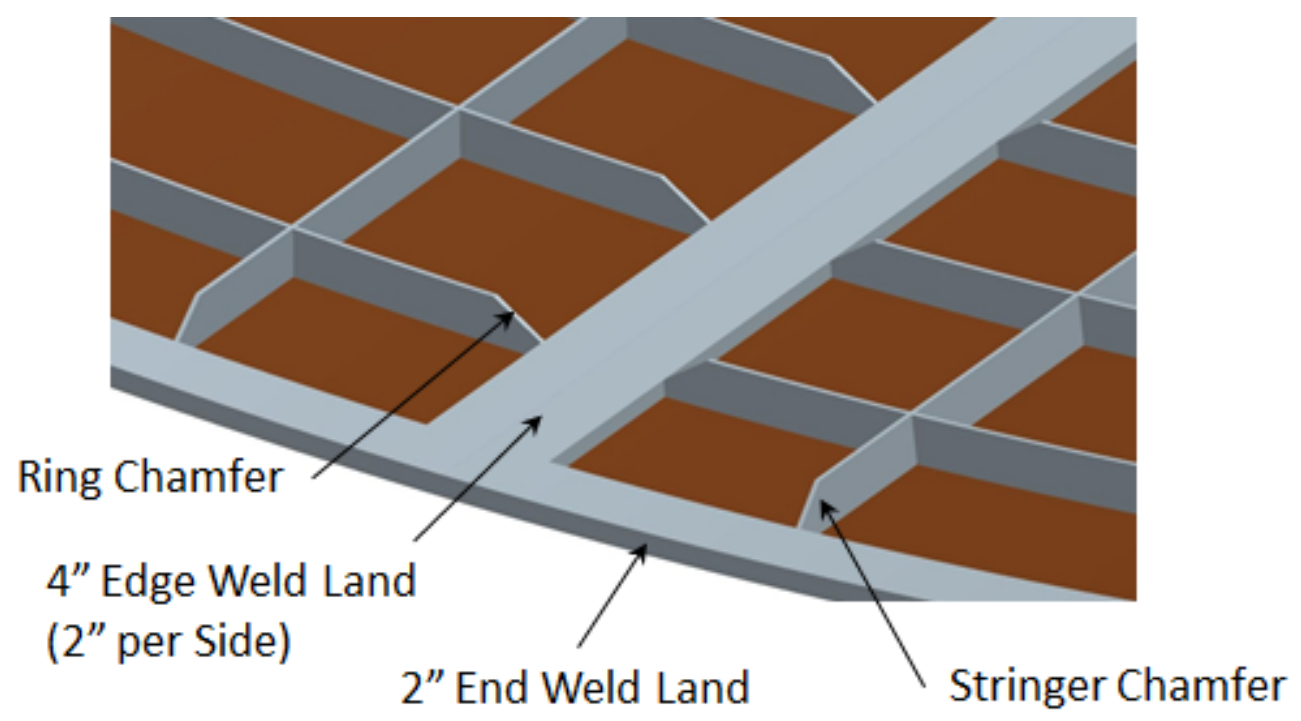

Figure 9. Metallic Cryotank Orthogrid Panel Baseline Weld Land Region.

\section{B. TRL 9 Reference Design}

Work by Thornburgh and Hilburger in Ref. 14 suggested placing adjacent orthogrid stiffeners as close as possible to the weld lands would help prevent weld land buckling. This design concept was implemented in the reference design by incorporating stiffeners along the weld land edges, effectively creating a C-channel. A comparison of the original design and modified weld land design is shown in Figures 10 (a) and (b). Additional assumptions used for the TRL 9 reference design are listed below:

1) Machining performed on both sides of gore panels (Provides symmetric buildups and eliminates induced moments)

2) Tapered weld lands are acceptable (Reduced weld land thickness of gores and adjacent components)

3) Eliminate tapers on ring frames and extend them to edge weld land stiffeners (Provides extra buckling support to stiffener)

4) Reduce thickness of monocoque skirt extensions until weight/inch matched barrel acreage (Captures weight of realistic skirt design without performing detailed sizing)

The team then developed a high-fidelity FEM in which the orthogrid stiffeners were modeled in the tank barrel including the adjacent orthogrid stiffeners as shown in Figure 11. The FEM also included additional transition components shown as pink and green colored components in the figure that allowed additional skin buildups near the weld lands to be sized. The total CAD mass of the reference cryotank design was reduced to 10,925 lbs. A breakdown of the CAD mass for the baseline and modified cryotank designs is shown in Table 4. Most of the mass savings can be attributed to the thinner weld lands in the upper and lower domes. The thinner weld lands were a direct result of the part symmetry associated with duel-sided machining. The weld land thickness in the domes ranged from 0.250 " to 0.390 " compared to a constant 0.450 " thick in the baseline design. In the barrel section, the weld land thickness was reduced from 0.680 " to 0.385 ". The addition of the edge weld land stiffeners eliminated the weld land buckling issues seen in the baseline design and resulted in a lighter overall barrel weight by reducing the skin and weld land thicknesses. It should be noted that the orthogrid height was not limited by the stock size restrictions for this relatively short, upper stage tank design. 


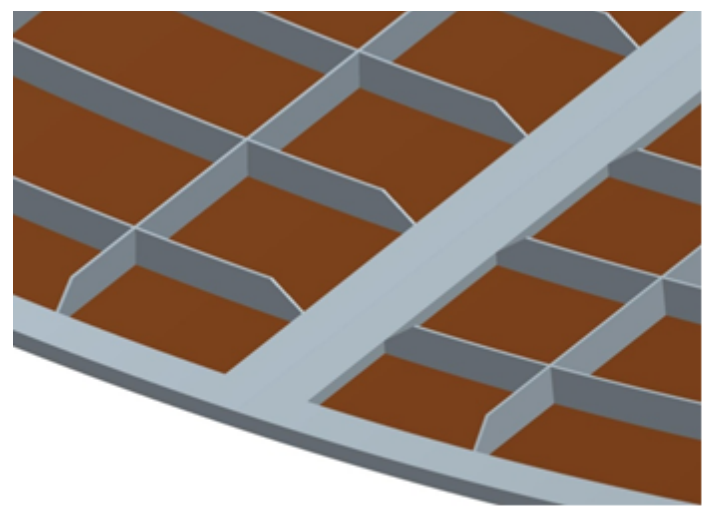

(a) Original Design

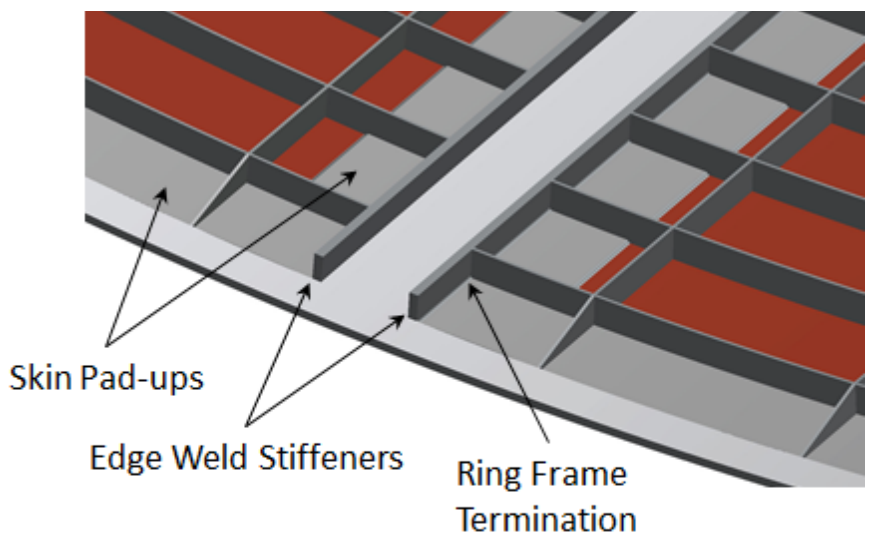

(b) Reduced Weight Design

Figure 10. Modified Barrel Weld Land Design.

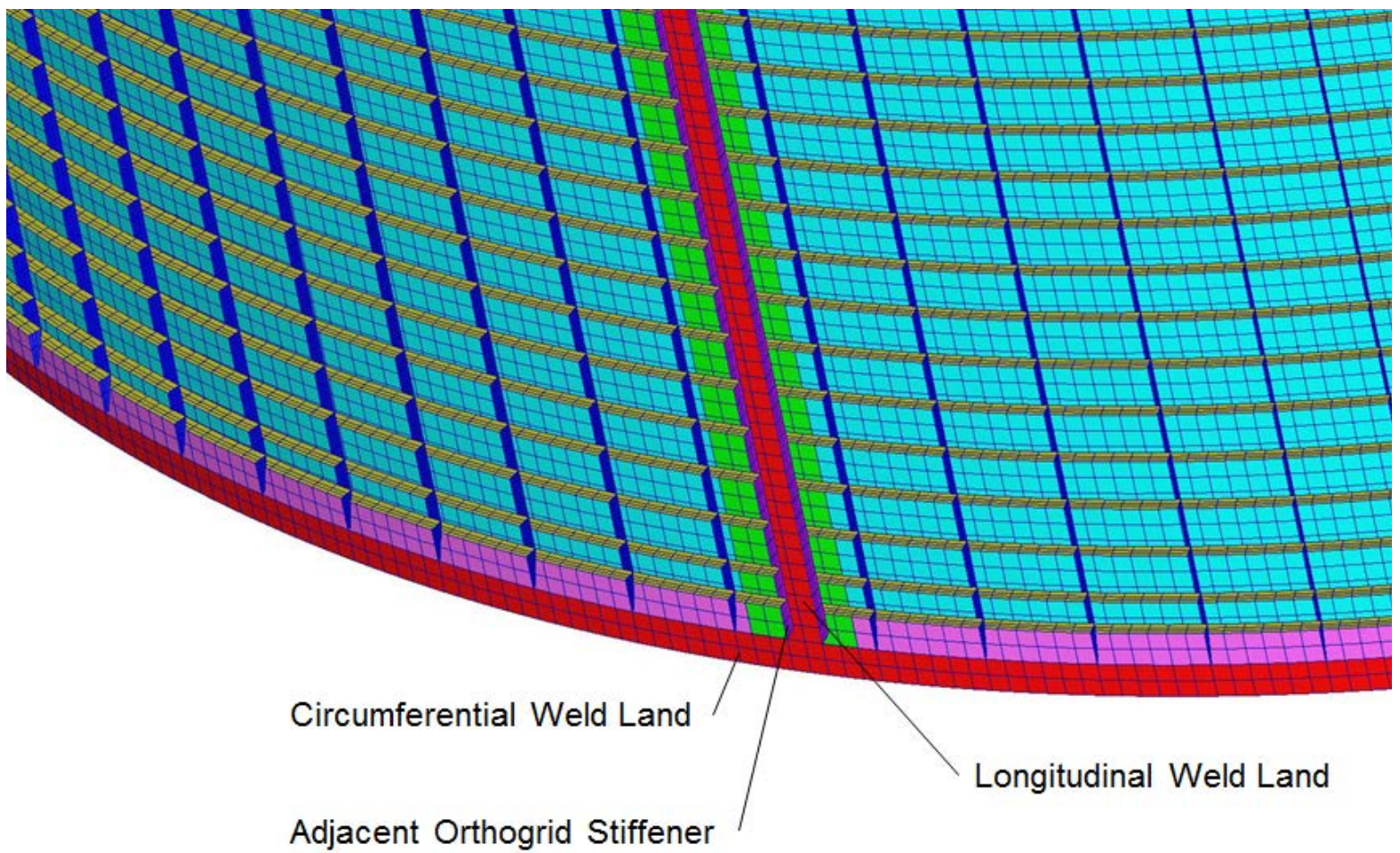

Figure 11. Detailed Metallic Cryotank Orthogrid Barrel Finite Element Model. 
Table 4. Metallic Cryotank Design Mass Breakdown.

\begin{tabular}{|c|c|c|c|c|c|c|}
\hline \multirow[b]{2}{*}{ Part } & \multicolumn{3}{|c|}{ CAD Mass (lbm) } & \multicolumn{2}{|c|}{ \% Mass Savings } & \multirow[t]{2}{*}{ Primary Design Change } \\
\hline & $\begin{array}{c}\text { Baseline } \\
\text { Design }\end{array}$ & $\begin{array}{c}\text { Modified } \\
\text { Design }\end{array}$ & Difference & $\begin{array}{c}\text { Part to } \\
\text { Part }\end{array}$ & Tank & \\
\hline Barrel & 3,748 & 3,550 & 198 & $5 \%$ & $2 \%$ & Weld Land Stiffeners \\
\hline Upper Dome & 3,644 & 3,234 & 410 & $11 \%$ & $3 \%$ & \multirow{2}{*}{$\begin{array}{l}\text { Symmetric Buildups, Tapered Weld Lands, } \\
\text { Thinner T-Joint due to Adjacent Structure }\end{array}$} \\
\hline Lower Dome & 3,677 & 3,269 & 408 & $11 \%$ & $3 \%$ & \\
\hline $\begin{array}{l}\text { Upper Skirt } \\
\text { Extension }\end{array}$ & 492 & 391 & 101 & $20 \%$ & $1 \%$ & $\begin{array}{l}\text { Thickness Adjustment to Match Barrel } \\
\text { Stiffness }\end{array}$ \\
\hline $\begin{array}{l}\text { Lower Skirt } \\
\text { Extension }\end{array}$ & 492 & 391 & 101 & $20 \%$ & $1 \%$ & $\begin{array}{l}\text { Thickness Adjustment to Match Barrel } \\
\text { Stiffness }\end{array}$ \\
\hline Fasteners & 90 & 90 & 0 & 0 & 0 & \\
\hline TOTAL & 12,143 & 10,925 & 1,217 & & $10 \%$ & \\
\hline
\end{tabular}

\section{Spun-Formed Dome Study}

In order to evaluate the mass savings potential of lower TRL advanced manufacturing techniques, the NASA team performed an additional trade study with aluminum lithium alloy cryotank designs that utilized partially or fully spun-formed domes. The current state-of-the-art spun-formed dome manufacturing technology has the capability of manufacturing metallic domes up to 16.4-foot $(5 \mathrm{~m})$ in diameter. The process involves friction stir welding of the stock material together to form a blank. This blank is then spun-formed to the desired shape. A preliminary sizing study was performed using HyperSizer on the 33-foot $(10 \mathrm{~m})$ metallic cryotank design for a 16.4foot $(5 \mathrm{~m})$ diameter spun-formed dome cap and a full 33-foot $(10 \mathrm{~m})$ diameter spun-formed dome manufactured with the Al-Li 2195-T8 alloy. The sizing results shown in Table 5 assume that the full Al-Li 2195-T8 temper is achieved after the domes are spin-formed and have the same thickness tolerance as the TRL 9 reference design. Figure 12 illustrates how the mass is reduced from the TRL 9 friction stir welded gore design to the lower TRL spun-formed dome designs. The dome mass numbers in the table do not include machining tolerances added to the optimized dome thicknesses.

Table 5. Metallic Cryotank Mass Summary with Spun-Formed Domes.

\begin{tabular}{|c|c|c|c|c|}
\hline $\begin{array}{c}\text { Approximate TRL Manufacturing } \\
\text { Technique }\end{array}$ & $\begin{array}{c}\text { Single Dome } \\
\text { Mass } \\
\text { (lbm) }\end{array}$ & $\begin{array}{c}\text { Savings Per } \\
\text { Dome } \\
\text { (lbm) }\end{array}$ & $\begin{array}{c}\text { \% Mass } \\
\text { Savings } \\
\text { (Dome) }\end{array}$ & $\begin{array}{c}\text { \% Mass } \\
\text { Savings } \\
\text { (Tank) }\end{array}$ \\
\hline $\begin{array}{c}\text { TRL 9 } \\
\text { Friction Stir Welded Gores }\end{array}$ & 3,234 & - & & \\
\hline $\begin{array}{c}\text { TRL 6 } \\
\text { 5m Spun-Formed Dome Cap }\end{array}$ & 3,174 & 60.0 & $1.9 \%$ & $1.1 \%$ \\
\hline $\begin{array}{c}\text { TRL 3 } \\
\text { Full 10m Spun-Formed Dome }\end{array}$ & 3,065 & 169.6 & $5.2 \%$ & $3.1 \%$ \\
\hline
\end{tabular}




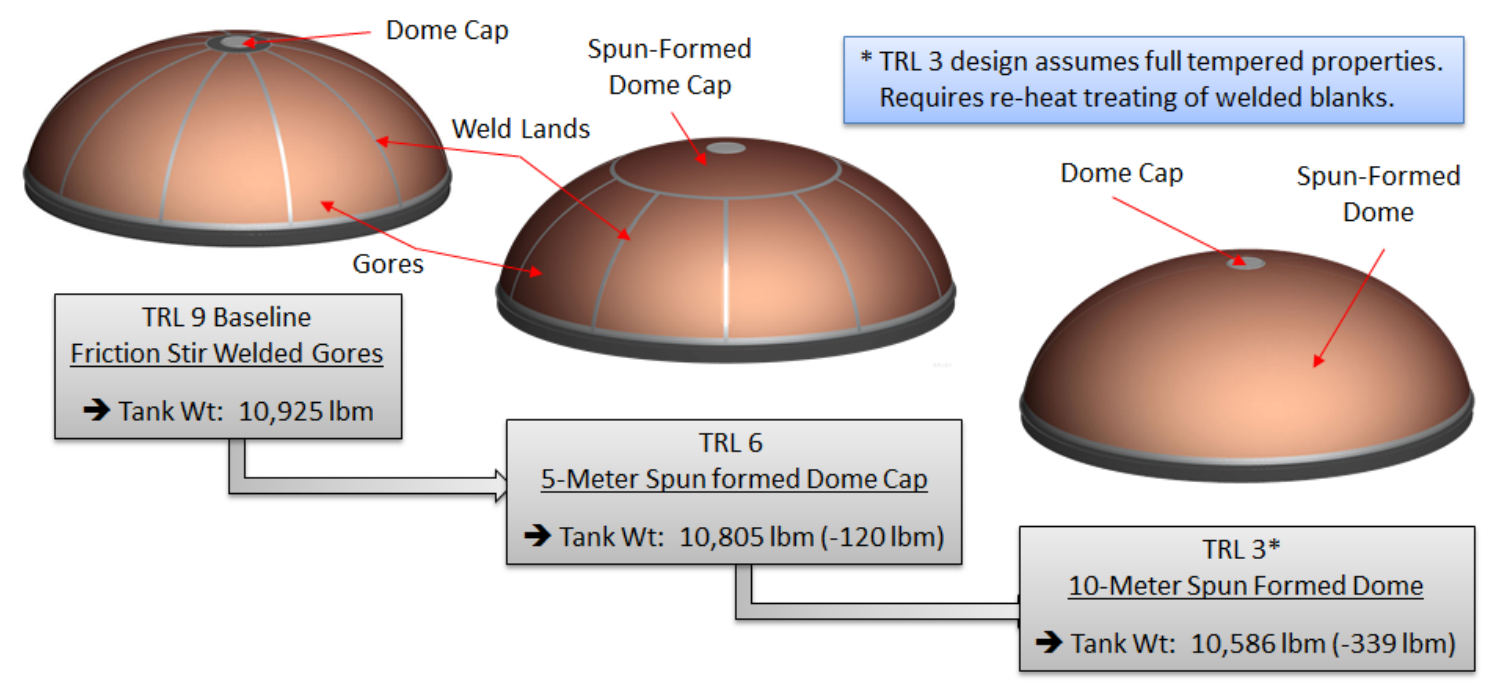

Figure 12. Potential Mass Savings with Spun-Formed Dome Manufacturing.

\section{Summary}

This paper presents the structural design and sizing details of a 33-foot (10 m) metallic cryotank concept used as the reference design to compare with the composite cryotank concepts developed by industry as part of NASA's Composite Cryotank Technology Development (CCTD) Project. The structural design methodology, sizing assumptions, and analysis results for the baseline and reference metallic cryotank concepts are reported in the paper. The paper also discusses the potential mass benefits of using advanced manufacturing techniques to spin-form the upper and lower cryotank domes. The baseline metallic cryotank design used one-side machining to minimize cost and smeared orthogrid section properties to simplify the sizing process. This resulted in a relatively high mass that was not representative of a TRL 9 cryotank. Opening up the design space and using a detailed 3-D finite element analysis to capture the orthogrid and weld land design details resulted in a TRL 9 reference design that showed a significant mass savings over the initial baseline metallic cryotank. The axial weld lands in the reference design barrel section incorporated integral weld land stiffeners to achieve the necessary buckling margin with minimal weight. The reference design also used duel-side machining to manufacture the dome gores. This symmetry eliminated the induced bending moment caused by eccentric loading and resulted in significant dome weight savings. The NASA team also explored the potential mass benefits of using advanced manufacturing techniques to spin-form the upper and lower cryotank domes. The performed analysis indicated that an additional 3.1\% mass savings over the TRL 9 reference design may be achievable if the domes can be spun-formed and still retain their full mechanical properties. The spun-formed metallic cryotank designs utilizing advanced metallic manufacturing techniques provided a representative weight comparison to the lower TRL composite cryotank designs. 


\section{References}

${ }^{1}$ Vickers, J.H., Fikes, J., Jackson, J.R., Johnson, T.F., Sutter, J. K., and Martin, R. A., “NASA Composite Cryotank Technology Demonstration: Overview,” SAMPE 2012 Conference and Exhibition, Baltimore, MD, 2012.

${ }^{2}$ Robinson, M. J., Hand, M. L., Luu, and Cao, C.M. Cao, “Design of Large Composite Cryogenic Tanks,” SAMPE 2012 Conference and Exhibition, Baltimore, MD, 2012.

${ }^{3}$ Johnson, T. F., Sleight, D.W., and Martin, R.A., "Structures and Design Phase I Summary for the NASA Composite Cryotank Technology Demonstration Project,” 54th AIAA/ASME/ASCE/AHS/ ASC Structures, Structural Dynamics, and Materials Conference, Boston, MA, April 2013.

${ }^{4}$ Mankins, J.C., “Technology Readiness Levels: A White Paper, ” NASA Office of Space Access and Technology, Advanced Concepts Office, April 1995.

${ }^{5}$ Pilet, J., Worden, M., Guillot, M., Diecidue-Conners, D., and Welzyn, K., “AIAA Technical Paper - External Tank Program - Legacy of Success,” AIAA SPACE 2011 Conference and Exposition, Long Beach, California, Sep. 27-29, 2011, AIAA-20117157.

${ }^{6}$ Curreri, P.A., Lollar, L.F., Torres, P.D., and Russell, C.K. (MSFC), Hoffman, E.K., Domack, M.S., Edahl, Jr., R.A., Shenoy, R.N., Cooks, R.E., and Tayon, W.A. (LaRC), Brewster, J., Bank, J., Pham, D., Li, T., and Reinmuller, R. (Lockheed Martin Space Systems Company), Steward, T., and Caratus, A. (Jacobs Engineering), and Schneider, J. (Mississippi State University), "Aluminum-Lithium, Friction Stir Welded, Spun-Formed Domes for Light-Weight Cryogenic Propellant Tanks Part I: 1-MeterDiameter Proof of Concept,” NASA/TP-11-216462, March 2011.

${ }^{7}$ Curreri, P.A., Lollar, L.F., Torres, P.D., and Russell, C.K. (MSFC), Hoffman, E.K., Domack, M.S., Edahl, Jr., R.A., Shenoy, R.N., Cooks, R.E., and Tayon, W.A. (LaRC), Brewster, J., Bank, J., Pham, D., Li, T., and Reinmuller, R. (Lockheed Martin Space Systems Company), Steward, T., and Caratus, A. (Jacobs Engineering), and Schneider, J. (Mississippi State University), "Aluminum-Lithium, Friction Stir Welded, Spun-Formed Domes for Light-Weight Cryogenic Propellant Tanks Part I: 1-MeterDiameter Proof of Concept,” NASA/TP-11-216462/Addendum, March 2011.

${ }^{8}$ Hales, S.J., Tayon, W.A, Domack, M.S., "Friction-Stir-Welded and Spin-Formed End Domes for Cryogenic Tanks," Proceedings of the 41 ${ }^{\text {st }}$ Structures and Mechanical Behavior Meeting, 2012 JANNAF Annual Meeting, May 2012.

${ }^{9}$ NASA-STD-5001A, “Structural Design and Test Factors of Safety for Spaceflight Hardware,” NASA Technical Standards Program, August 2008.

${ }^{10}$ CxP 70135, “Constellation Program Structural Design and Verification Requirements,” National Aeronautics and Space Administration (NASA), Washington, DC., December 2007.

${ }^{11}$ NASA-SP-8007, "Buckling of Thin-Walled Circular Cylinders," NASA Space Vehicle Design Criteria, 1965.

${ }^{12}$ HyperSizer Structural Sizing Software, Collier Research Corp., Ver. 6.1, Hampton, VA, http://www.hypersizer.com, 2011.

${ }^{13}$ MSC Nastran, MSC Software Corporation, Ver. 2011, Santa Ana, http://www.mscsoftware.com, 2011.

${ }^{14}$ Thornburgh, R.P., Hilburger, M.W., “Longitudinal Weld Land Buckling in Compression-Loaded Orthogrid Cylinders,” NASA/TM-2010-216876, ARL-TR-5121, December 2010. 